\title{
Liliane Hilaire-Pérez, La pièce et le geste. Artisans, marchands et savoir technique à Londres au XVIII siècle
}

Paris, Éditions Albin Michel, « L'Évolution de l'humanité », 2013

\section{Francesca Bray}

\section{(2) OpenEdition}

1 Journals

Electronic version

URL: http://journals.openedition.org/artefact/539

DOI: 10.4000/artefact.539

ISSN: 2606-9245

Publisher:

Association Artefact. Techniques histoire et sciences humaines, Presses universitaires du Midi

Printed version

Date of publication: 1 October 2016

Number of pages: 403-406

ISBN: 978-2-7535-5174-9

ISSN: 2273-0753

Electronic reference

Francesca Bray, «Liliane Hilaire-Pérez, La pièce et le geste. Artisans, marchands et savoir technique à Londres au xvIII' siècle ", Artefact [Online], 4 | 2016, Online since 07 July 2017, connection on 24

September 2020. URL : http://journals.openedition.org/artefact/539; DOI : https://doi.org/10.4000/ artefact.539

This text was automatically generated on 24 September 2020.

Artefact, Techniques, histoire et sciences humaines est mise à disposition selon les termes de la Licence Creative Commons Attribution - Pas d'Utilisation Commerciale - Pas de Modification 4.0 International. 


\section{Liliane Hilaire-Pérez, La pièce et le geste. Artisans, marchands et savoir technique à Londres au XVIII siècle}

Paris, Éditions Albin Michel, «L'Évolution de l'humanité », 2013

Francesca Bray

\section{REFERENCES}

Liliane Hilaire-Pérez, La pièce et le geste. Artisans, marchands et savoir technique à Londres au XVIII siècle, Paris, Éditions Albin Michel, « L'Évolution de l'humanité », 2013, 459 p.

In her magnificent new study Liliane Hilaire-Pérez propounds the paradoxical argument that a Smithian, qualitative, organic and product-oriented rationality was the keystone of eighteenth-century British success in manufacturing. Finely argued and richly documented, La pièce et le geste will be welcomed by historians of Europe and global historians as a stimulating and convincing contribution to rethinking the genealogies of industrial society. Historians of technology will further welcome La pièce et le geste as a significant step forward in conceptualising articulations and transitions between modes of production.

2 The recent turn to global history has reinstated Smithian growth as a living force in the emergence of the modern industrial world. Investigating the entanglements, convergences and co-constitution of Chinese, Indian and European technical skills, systems of production and regimes of consumption through the early modern period and into the nineteenth century, the new global history of manufactures and commodities prompts us to think afresh about the foundations and genealogies of industrial technical thinking and values, as well as the multiple paths, seldom linear, which different societies followed towards lesser or greater industrialisation in the modern era. 
3 The challenge is particularly daunting and rewarding in the domain of history of technology, whether taken in the anglophone sense of the history of making and doing (histoire des techniques), or in the francophone meaning of the history of conceptualising skills and techniques (histoire de la technologie). It is challenging for several reasons. One is the heavy weight of common sense and scholarly traditions which insist that artisanal and industrial ways of working are distinct and incompatible. If we are interested in analysing entanglements and transitions rather than ruptures, where do we look for sources, what terminology or practices do we trace, and how do we frame the enquiry?

4 For me it is at this conceptual-analytical level that Hilaire-Pérez's study makes its most significant contribution. There is indeed a clear distinction to be drawn between the technological rationality based on an industrial economic logic, a quantitative logic which translates human work and material product into the abstractions of labour and commodity, on the one hand, and on the other a technological rationality based upon what Hilaire-Pérez calls an economy of the product, a qualitative vision in which the geste cannot be separated from its skill, nor the pièce from its design and execution. It was the latter technological philosophy that led Adam Smith and other eighteenthcentury British thinkers to identify the production of goods as a source not only of monetary wealth but also of social cohesion and aesthetic value, recognising the pleasure of producing or possessing an object that fits the hand or delights by its action, a finely designed and finely wrought piece that represents the concerted skills of many workers. In this logic a finished piece, whether it be a musical clock or a brass hinge, constitutes a microcosm of the social machine.

5 As early as the 1830s, however, British political economists, engineers and businessmen began to expound and promote a new science and philosophy of mechanisation. Among the foundational figures in establishing industrial rationality as practical common sense were Charles Babbage (On the Economy of Machinese and Manufactures, 1832), Andrew Ure (The Philosophy of Manufactures: an Exposition of the Scientific, Moral and Commercial Economy of the Factory System of Great-Britain, 1835), and William Rankine, professor of Engineering at the University of Glasgow, a pioneer in promoting technology as a scientific discipline. Babbage, Ure, Rankine and their colleagues formulated a rationality of technical efficiency based upon the disaggregation of work processes into a sequence of component units, replacing as many manual tasks as possible by machines and thus accelerating and standardising production. In presenting this project as the reduction of human drudgery, the new technologie attributed both material and moral benefits to the displacement of skills and strength from a network of craft-workers to the machine and the assembly-line.

6 As the mantra of industrial efficiency ${ }^{1}$ was consolidated through the nineteenth century by the expansion of factories, the rise of the engineering profession and the introduction of training programmes to educate "intelligent workmen", it became common sense to think of the shift from trades to industrial production not as a transition but as a revolution, a rupture in ways of seeing, thinking and doing that ushered in a new world. From Heidegger and Ellul's techno-despair to Landes and Mokyr's techno-triumphalism, philosophers and historians, including specialists of the history of technology and of technological thought, have typically treated the rationalities and aesthetics of craft and mechanisation as dichotomous and incompatible. Whether as historians of technology or of technologie, we have signally 
failed in bridging this analytical chasm and in disentangling how a new mode of making and thinking might gradually take root as the established mode evolves and diversifies to meet new demands. This is the task that Liliane Hilaire-Pérez sets herself in La pièce et le geste.

Liliane Hilaire-Pérez's choice of London as her case study allows her to investigate her paradox in minute detail, and to test her findings across a variety of trades and materials. There are few historical sites where the making and purchasing of commodities are more richly documented than in the great European capitals of the eighteenth century. Eighteenth-century London offered an increasing profusion of complex assembled goods, ranging from luxuries for wealthy connoisseurs to readymades for ordinary citizens. Carriage-makers and clocksmiths, and the smiths or later the ironmongers who supplied them with components and tools in the form of springs, hinges and brackets, files and bolts - all these firms kept accounts and order-books with lists of clients and workmen. They took out insurance policies, applied for patents, registered designs, sent models of components out to suppliers or registered inventories as they filed for bankruptcy. An abundance of these sources is archived for London firms. What is particularly useful is that such sources are descriptive of actual material and social practice, not prescriptive models or abstractions - they tell us what worked and what did not, who worked with whom, and how inventories, materials, designs, components and the terms for working practices changed over time.

Given the recent resurgence of interest among historians of science and technology in automata and other mechanical toys ${ }^{2}$, readers will appreciate the attention that Liliane Hilaire-Pérez gives to firms producting "toy-wares ", a category understood by eighteenth-century commentators as curious objects that stimulated scientific reflection and technical ingenuity, bridging the worlds of philosophy and everyday life. George Willdey's firm offered slides for magic-lanterns and spy-glasses but earned its way by selling ordinary reading-glasses, while also supplying scientists with lenses for their instruments. Over the years the Vulliamy family not only sold fantastical clocks to the aristocracy but made a regular income by checking, adjusting and maintaining their customers' clocks and watches, ordinary or extraordinary. New trades came into being to supply the ever-diversifying needs of famous workshops and more mundane purveyors of everyday goods. People felt the need of a term for ironmonger for several decades before the word caught on. While the term ironmonger hardly acknowledged the new importance of different types of brass in that tradesman's repertory, it does perfectly capture the advances in iron and steel manufacturing that now provided the almost infinite repertory of tools, materials, surfaces and designs that the ironmonger stocked and supplied for assembling, mending and adapting such valuable, cunningly assembled pieces as a carriage or a carriage-clock, or such routine bourgeois needs as a candlestick or door-knobs.

9 As the trades and the goods they fabricated became increasingly diverse, so too did the terminology, not only of components, materials and finishes, but also of specialised skills and actions (see for example the Jobbing List reproduced on p. 418). Meanwhile, over the eighteenth century the price of skilled work rose against that of materials, reversing the earlier calculus for pricing a job or a piece. While the new terminology and calculations of value were hardly systematic, and certainly remained far from the standardised quantifications of Taylorism, they nevertheless conveyed a new concern with the analysis and classification of operations, and a new sophistication in the 
terminology for and pricing of gestures. Yet although we might be tempted to think of these complex eighteenth-century processes of assembling diverse components into a single finished object as a prototype of the industrial assembly line, there was a fundamental difference at the core of the organisation of production. When it came to adjusting the mechanism, each clock had, in a sense, its own life-history and personality; when a carriage was brought in for overhaul, it might need rebalancing or be judged to benefit from a newly developed type of spring. As long as a single firm offered the building, checking, maintainance and repair of such items as clocks or carriages under the same roof, work, judgement and assembly by analogy remained the rule.

10 As the account and order books dissected in La pièce et le geste make clear, London's success in the late eighteenth century in producing such an enviable range of highquality assembled goods, ranging from luxuries to affordable everyday goods, depended increasingly upon the availability of new industrial materials and components supplied by Birmingham and Sheffield. Conversely, industrialisation in Birmingham and Sheffield fed off the growing London market. Liliane Hilaire-Pérez thus shows us the gradual and mutually qualified processes through which both the industrialisation of manufacturing processes and operational thinking of the industrial type began to take shape, catalysed by the diversification and specialisation of the London world of « bespoke » trades.

11 Knowing how few of my colleagues read French, I sincerely hope that La pièce et le geste will be translated in order to reach the audience it deserves among young historians of technology, and indeed among STS scholars. In addition to the invaluable insights Liliane Hilaire-Pérez brings to our understanding of the historical genealogy of industrial logic, her study offers a salutory reminder that even the automated industrial processes of contemporary society still depend on gestural skills, social coordination and qualitative judgement.

\section{NOTES}

1. See Jennifer KARNS ALEXANDER, The Mantra of Efficiency: From Waterwheel to Social Control, Johns Hopkins University Press. 2010.

2. As an example, Adelheid voskuHL's Androids in the Enlightenment: Mechanics, Artisans, and Cultures of the Self (University of Chicago Press, 2013) won the Jacques Barzun Prize in Cultural History of the American Philosophical Society for 2014. 


\section{AUTHORS}

FRANCESCA BRAY

Social Anthropology, University of Edinburgh 